\title{
MANAJEMEN MUTU PENDIDIKAN DALAM MENGHADAPI KREATIVITAS ANAK
}

\section{Syahril Chaniago*}

\begin{abstract}
Many people in society are not satisfied with the quality of education in our country. Obviously we often hear phrases like, "our country hasn't had good quality of education yet", "development of education in Indonesia is very slow and left behind from other countries", "when are we going to make progress if our education system is still running in place". Therefore, the most important thing to think about is to produce intelligent and competitive human beings.
\end{abstract}

Keywords : Management of Quality Education, Intelligent, and creativity.

\section{PENDAHULUAN}

Para ahli pendidikan telah sepakat bahwa suatu sistem pendidikan dapat dikatakan berkualitas, apabila proses kegiatan belajar-mengajar berjalan secara menarik dan menantang sehingga peserta didik dapat belajar sebanyak dan sebaik mungkin melalui proses belajar yang berkelanjutan. Proses pendidikan yang bermutu akan menghasilkan hasil yang bermutu serta relevan dengan perkembangan zaman. Agar terwujud sebuah pendidikan yang bermutu dan

* Syahril Chaniago. Dosen Universitas Pakuan Bogor. efisien, maka perlu disusun dan dilaksanakan program-program pendidikan yang mampu membelajarkan peserta didik secara berkelanjutan, karena dengan mutu pedidikan yang optimal, diharapkan akan menghasilkan keunggulan sumber daya manusia yang dapat menguasai pengetahuan, keterampilan dan keahlian sesuai dengan ilmu pengetahuan dan teknologi yang terus berkembang secara pesat. 


\section{MANAJEMEN PENDIDIKAN, KECERDASAN, DAN KREATIVI- TAS}

Untuk dapat mencapai sebuah pendidikan yang berkualitas diperlukan manajemen pendidikan yang mampu memobilisasi segala sumber daya pendidikan. Di antaranya adalah manajemen peserta didik yang isinya merupakan pengelolaan dan juga pelaksanaannya. Masih banyak kita temukan fakta-fakta di lapangan sistem pengelolaan anak didik yang masih mengunakan cara-cara konvensional dan lebih menekankan pengembangan kecerdasan dalam arti yang sempit dan tentunya kurang memberi perhatian kepada pengembangan bakat kreatif peserta didik. Padahal Kreativitas disamping bermanfaat untuk pengembangan diri anak didik juga merupakan kebutuhan akan perwujudan diri sebagai salah satu kebutuhan paling tinggi bagi manusia. Kreativitas adalah proses merasakan dan mengamati adanya masalah, membuat dugaan tentang kekurangan, menilai dan meguji dugaan atau hipotesis, kemudian mengubahnya dan mengujinya lagi sampai pada akhirnya menyampaikan hasilnya. Dengan adanya kreativitas yang diimplementasikan dalam sistem pembelajaran, peserta didik nantinya diharapkan dapat menemukan ide-ide yang berbeda dalam memecahkan masalah yang dihadapi sehingga ide-ide kaya yang progresif dan divergen pada nantinya dapat bersaing dalam kompetisi global yang selalu berubah.

Perubahan kualitas yang seimbang baik fisik maupun mental merupakan indikasi dari perkembangan anak didik yang baik. Tidak ada satu aspek perkambangan dalam diri anak didik yang dinilai lebih penting dari yang lainnya. Oleh itu tidaklah salah bila teori kecerdasan majemuk yang diutarakan oleh Gardner dinilai dapat memenuhi kecenderungan perkembangan anak didik yang bervariasi.

Maka penyelenggaraan pendidikan saat ini harus diupayakan untuk memberikan pelayanan khusus kepada peserta didik yang mempunyai kreativitas dan juga keberbakatan yang berbeda agar tujuan pendidikan dapat diarahkan menjadi lebih baik.

Muhibbin Syah menjelaskan bahwa akar kata dari pendidikan adalah "didik" atau "mendidik" yang secara harfiah diartikan memelihara 
dan memberi latihan. Sedangkan "pendidikan", merupakan tahapantahapan kegiatan mengubah sikap dan perilaku seseorang atau sekelompok orang melalui upaya pelatihan dan pengajaran. Hal ini mengindikasikan bahwa pendidikan tidak dapat lepas dari pengajaran. Kegiatan dari pengajaran ini melibatkan peserta didik sebagai penerima bahan ajar dengan maksud akhir dari semua hal ini sesuai yang diamanatkan dalam undang-undang no. 20 tentang sisdiknas tahun 2003; agar peserta didik secara aktif mengembangkan potensi dirinya untuk memiliki kekuatan spiritual keagamaan, pengendalian diri, kecerdasan, akhlak mulia, serta keterampilan yang diperlukan dirinya, masyarakat, bangsa dan negara.

Dalam pendidikan, peserta didik merupakan titik fokus yang strategis karena kepadanyalah bahan ajar melalui sebuah proses pengajaran diberikan. Dan sudah mafhum bahwa peserta didik memiliki kekurangan dan kelebihannya masing-masing, mereka unik dengan seluruh potensi dan kapasitas yang ada pada diri mereka dan keunikan ini tidak dapat diseragamkan dengan satu aturan yang sama antara peserta didik yang satu dengan peserta didik yang lain. Para pendidik dan lembaga pendidikan harus menghargai perbedaan yang ada pada mereka. Keunikan yang terjadi pada peserta didik memang menimbulkan satu permasalahan tersendiri yang harus diketahui dan dipecahkan sehingga pengelolaan murid (peserta didik) dalam satu kerangka kerja yang terpadu mutlak diperhatikan, terutama pertimbangan pada pengembangan kreativitas, hal ini harus menjadi titik perhatian karena sistem pendidikan memang masih diakui lebih menekankan pengembangan kecerdasan dalam arti yang sempit dan kurang memberikan perhatian kepada pengembangan kreatif peserta didik. Hal ini terjadi dari konsep kreativitas yang masih kurang dipahami secara holistic, juga filsafat pendidikan yang sejak zaman penjajahan bermazhabkan azas tunggal seragam dan berorientasi pada kepentingankepentingan, sehingga pada akhirnya berdampak pada cara mengasuh, mendidik dan mengelola pembelajaran peserta didik.

Kebutuhan akan kreativitas tampak dan dirasakan pada semua kegiatan manusia. Perkembangan akhir dari kreativitas akan terkait 
dengan empat aspek, yaitu: aspek pribadi, pendorong, proses dan produk. Kreativitas akan muncul dari interaksi yang unik dengan lingkungannya.Kreativitas adalah proses merasakan dan mengamati adanya masalah, membuat dugaan tentang kekurangan (masalah) ini, menilai dan mengujinya. Proses kreativitas dalam perwujudannya memerlukan dorongan (motivasi intristik) maupun dorongan eksternal. Motivasi intrinstik ini adalah intelegensi, memang secara historis kretivitas dan keberbakatan diartikan sebagai mempunyai intelegensi yang tinggi, dan tes intellejensi tradisional merupakan ciri utama untuk mengidentifikasikan anak berbakat intelektual tetapi pada akhirnya hal inipun menjadi masalah karena apabila kreativitas dan keberbakatan dilihat dari perspektif intelejensi berbagai talenta khusus yang ada pada peserta didik kurang diperhatikan yang akhirnya melestarikan dan mengembang biakkan Pendidikan Tradisional Konvensional yang berorientasi dan sangat menghargai kecerdasan linguistik dan logika matematik. Padahal, Teori psikologi pendidikan terbaru yang menghasilkan revolusi paradigma pemikiran tentang konsep kecerdasan diajukan oleh Prof. Gardner yang mengidentifikasikan bahwa dalam diri setiap anak apabila dirinya terlahir dengan otak yang normal dalam arti tidak ada kerusakan pada susunan syarafnya, maka setidaknya terdapat delapan macam kecerdasan yang dimiliki oleh mereka.

$$
\text { Undang-undang No.20 }
$$

tentang sistem pendidikan nasional tahun 2003, perundangan itu berbunyi " warga negara yang memiliki kelainan fisik, emosional, mental, intelektual, dan/atau sosial berhak memperoleh pendidikan khusus". Baik secara tersurat ataupun tersirat UU No.20 tersebut telah mengamanatkan untuk adanya pengelolaan pelayanan khusus bagi anak-anak yang memiliki bakat dan kreativitas yang tinggi.

Pengertian dari pendidikan khusus disini merupakan penyelenggaraan pendidikan untuk peserta didik yang berkelainan atau peserta didik yang memiliki kecerdasan luar biasa yang diselenggarakan secara inklusif atau berupa satuan pendidikanpendidikan khusus pada tingkat pendidikan dasar dan menengah. Pada akhirnya memang diperlukan adanya suatu usaha rasional dalam 
mengatur persoalan-persoalan yang timbul dari peserta didik karena itu adanya suatu manajemen peserta didik merupakan hal yang sangat penting untuk diperhatikan.

Siswa berbakat di dalam kelas mungkin sudah menguasai materi pokok bahasan sebelum diberikan. Mereka memiliki kemampuan untuk belajar keterampilan dan konsep pembelajaran yang lebih maju. Untuk menunjang kemajuan peserta didik diperlukan modifikasi kurikulum. Kurikulum secara umum mencakup semua pengalaman yang diperoleh peserta didik di sekolah, di rumah, dan di dalam masyarakat dan yang membantunya mewujudkan potensi-potensi dirinya. Jika kurikulum umum bertujuan untuk dapat memenuhi kebutuhan pendidikan pada umumnya, maka saat ini haruslah diupayakan penyelenggaraan kurikulum yang berdiferensi untuk memberikan pelayanan terhadap perbedaan dalam minat dan kemampuan peserta didik. Dalam melakukan kurikulum yang berbeda terhadap peserta didik yang mempunyai potensi keberbakatan yang tinggi, guru dapat merencanakan dan menyiapkan materi yang lebih kompleks, menyiapkan bahan ajar yang berbeda, atau mencari penempatan alternatif bagi siswa. Sehingga setiap peserta didik dapat belajar menurut kecepatannya sendiri.

Dalam paradigma berpikir masyarakat Indonesia tentang kreativitas, cukup banyak orangtua dan guru yang mempunyai pandangan bahwa kreativitas itu memerlukan iklim keterbukaan dan kebebasan, sehingga menimbulkan konflik dalam pembelajaran atau pengelolaan pendidikan, karena bertentangan dengan disiplin. Cara pandang ini sangatlah tidak tepat. Kreativitas justru menuntut disiplin agar dapat diwujudkan menjadi produk yang nyata dan bermakna. Displin disini terdiri dari disiplin dalam suatu bidang ilmu tertentu karena bagaimanapun kreativitas seseorang selalu terkait dengan bidang atau domain tertentu, dan kreativitas juga menuntut sikap disiplin internal untuk tidak hanya mempunyai gagasan tetapi juga dapat sampai pada tahap mengembangkan dan memperinci suatu gagasan atau tanggungjawab sampai tuntas.

Suatu yang tidak terbantahkan jika masa depan membutuhkan generasi yang memiliki kemampuan menghadapi 
tantangan dan perubahan yang terjadi dalam era yang semakin mengglobal. Tetapi penyelenggaraan pendidikan di Indonesia saat ini belum mempersiapkan para peserta didik dengan kemampuan berpikir dan sikap kreatif yang sangat menentukan keberhasilan mereka dalam memecahkan masalah.

Kebutuhan akan kreativitas dalam penyelenggaraan pendidikan dewasa ini dirasakan merupakan kebutuhan setiap peserta didik. Dalam masa pembangunan dan era yang semakin mengglobal dan penuh persaingan ini setiap individu dituntut untuk mempersiapkan mentalnya agar mampu menghadapi tantangan-tantangan masa depan. Oleh karena itu, pengembangan potensi kreatif yang pada dasarnya ada pada setiap manusia terlebih pada mereka yang memiliki kemampuan dan kecerdasan luar biasa perlu dimulai sejak usia dini, Baik itu untuk perwujudan diri secara pribadi maupun untuk kelangsungan kemajuan bangsa.

Dalam pengembangan bakat dan kreativitas haruslah bertolak dari karakteristik keberbakatan dan juga kreativitas yang perlu dioptimalkan pada peserta didik yang meliputi ranah kognitif, afektif, dan psikomotor. Motivasi internal ditumbuhkan dengan memperhatikan bakat dan kreativitas individu serta menciptakan iklim yang menjamin kebebasan psikologis untuk ungkapan kreatif peserta didik di lingkungan rumah, sekolah, dan masyarakat.

\section{KESIMPULAN}

Merupakan suatu tantangan bagi penyelenggaraan pendidikan di Indonesia untuk dapat membina serta mengembangkan secara optimal bakat, minat, dan kemampuan setiap peserta didik sehingga dapat mewujudkan potensi diri sepenuhnya agar nantinya dapat memberikan sumbangan yang bermakna bagi pembangunan masyarakat dan negara. Teknik kreatif ataupun taksonomi belajar pada saat ini haruslah berfokus pada pengembangan bakat dan kreativitas yang diterapkan secara terpadu dan berkesinambungan pada semua mata pelajaran sesuai dengan konsep kurikulum berdiferensi untuk siswa berbakat. Dengan demikian diharapkan nantinya akan dihasilkan produkproduk dari kreativitas itu sendiri 
dalam bidang sains, teknologi, olahraga, seni dan budaya. Amin

\section{DAFTAR PUSTAKA}

Depdikanas, UndangUndang Republik Indonesia Nomor 20 Tahun 2003 Tentang Pendidikan Nasional, Jakarta: Depdiknas, 2003.

De Porter, B and M. 1999,Hernacki Quantum Lerning: Membiasakan Belajar nyaman dan Menyenagkan, terjemahan Alawiyah Abdurahman,J akarta, Kaifa Gordon Dryden dan Jeannette Voss, 2000. Revolusi Cara Belajar bag.1, Bandung : Kaifa.
Husen dan Torsten, 1995. The Learning Society : Jakarta : PT. Raja Grafindo Persada.

Munandar, Utami, 1999. Kreativitas dan Keberbakatan; Strategi Mewujudkan Potensi Kreatif dan Bakat, Jakarta : PT. Gramedia Pusataka Utama.

Syah,Muhibbin, $1999 . \quad$ Psikologi Pendidikan Dengan Pendekatan Terbaru, Bandung : PT. Remaja Rosda Karya.

Tilaar, 1992. Manajemen Pendidikan nasional; Kajian Pendidikan Masa Depan, Bandung : PT. Remaja Rosdakarya. 